\title{
The Impact of Composed Songs on Vocabulary Acquisition among Japanese Language Learners in Malaysian University
}

\author{
Muhammad Alif Redzuan Abdullah, Sanimah Hussin
}

To Link this Article: http://dx.doi.org/10.6007/IJARBSS/v10-i11/7773

DOI:10.6007/IJARBSS/v10-i11/7773

Received: 07 September 2020, Revised: 10 October 2020, Accepted: 12 November 2020

Published Online: 29 November 2020

In-Text Citation: (Abdullah, \& Hussin, 2020)

To Cite this Article: Abdullah, M. A. R., \& Hussin, S. (2020). The Impact of Composed Songs on Vocabulary Acquisition among Japanese Language Learners in Malaysian University. International Journal of Academic Research in Business and Social Sciences. 10(11), 904-914.

\section{Copyright: (c) 2020 The Author(s)}

Published by Human Resource Management Academic Research Society (www.hrmars.com) This article is published under the Creative Commons Attribution (CC BY 4.0) license. Anyone may reproduce, distribute, translate and create derivative works of this article (for both commercial and non-commercial purposes), subject to full attribution to the original publication and authors. The full terms of this license may be seen at: http://creativecommons.org/licences/by/4.0/legalcode

$$
\text { Vol. 10, No. 11, 2020, Pg. } 904 \text { - } 914
$$

Full Terms \& Conditions of access and use can be found at http://hrmars.com/index.php/pages/detail/publication-ethics 


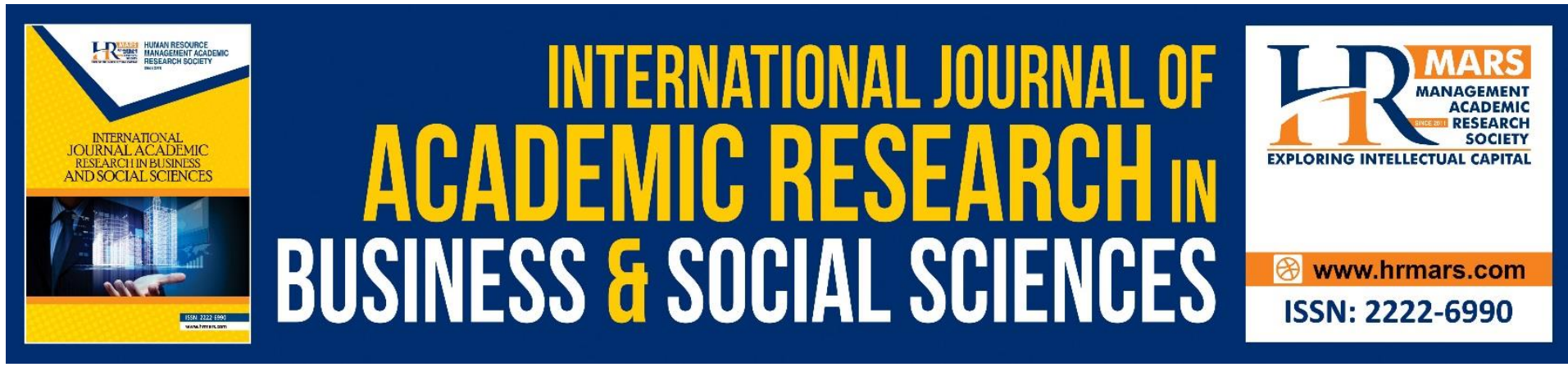

\section{The Impact of Composed Songs on Vocabulary Acquisition among Japanese Language Learners in Malaysian University}

Muhammad Alif Redzuan Abdullah, Sanimah Hussin

Faculty of Modern Languages and Communication, Universiti Putra Malaysia, Selangor, Malaysia

Email: muhammadalif@upm.edu.my, sanimah@upm.edu.my

\section{Abstract}

This is experimental approach research to investigate the relative effectiveness of the use of composed songs includes the lyrics and music on vocabulary acquisition among Basic Japanese language learners in the local public university of Malaysia. Although a few empirical studies have proven the effectiveness of songs on foreign language learning, this study would like to study the efficacy of the songs created by the researcher and composed specifically based on the content of the basic Japanese level 1 syllabus to be used in the Japanese as a foreign language (JFL) among Malaysian students. Moreover, it will investigate the effectiveness of songs towards students from the perspective of cognitive, affective, and psychomotor skills. This quantitative study used a questionnaire with 30 items was administered as the main data collection instrument and also class observation notes as additional research data to support the findings from the questionnaire. The data were coded and analysed using SPSS software version 22. The findings of the study show that learning through songs establishes a stress-free atmosphere and eliminates the affective filter which minimizes learning when it is high. Furthermore, listening to songs can assist the Japanese as a foreign language (JFL) learners overcome psychological barriers such as; anxiety and lack of confidence since learners actively get involved in self-learning. This study concludes that learning vocabulary from songs is an effective way to song help learners in learning pronunciation, spelling, meaning, and usage in varying degrees as they arouse learners' interest and motivation.

Keywords: Composed Songs, Japanese Language, Vocabulary Acquisition, Affective Hypothesis, Foreign Language.

\section{Introduction}

The Japanese language can be broken down into two basic components in spoken or written form are vocabulary and grammar. Vocabulary is the meaning aspect units of the language and, the grammar provides the rules and structures to assemble these units. In many contexts of daily life, messages can be conveyed if the grammar aspect is neglected but there is nothing that can be conveyed without any vocabulary. This is supported by several scholars such as Wilkins (1972); Arnaud and Sauvignon (1997); Meara (1980); and Brown (1993) that insufficient vocabulary knowledge is one of the major factors that hinder oral communication 
in the language classroom. Besides, there are researchers such as Nation (2007), Thornbury (2002) and Barcroft (2012) have argued that the development of vocabulary benefits the use of the target language and the lack of it may result in poor communication.

The vocabulary in Japanese is defined as 語彙 (Goi). The vocabulary or Goi is the main problem faced by students in the process of learning Japanese at Malaysian university because the large size of vocabulary which about 1000 vocabulary to be memorized and various forms of vocabulary which are not easy to learn and remember for communication. According to Tanaka (1984), the vocabulary in Japanese can be categorized into Wago (和語), Kango (漢語), Gairaigo (外来語), and Konshugo (混種語). The first category is Wago (和語) is also referred to as Yamato Kotoba, literally mean 'Japanese words' because the word ' $W a$ " and 'Yamato' described to Japan. This term is used to refer to words which can be traced back to the Yamato Kingdom, an ancient Kingdom before Chinese influence, and to words whose pronunciation and morphology is in accord with native Japanese linguistic conventions (Umesao, Kindaichi, Sakakura \& Hinohara 1989). The second category is Kango (漢語) literally means 'Chinese words' that were introduced from China in the various era and also called as Sino-Japanese words (Kindaichi et al., 1988; Shibatani, 1990). These words comprise kanji that are read using the pronunciation derived from Chinese.

The third category is Gairaigo (外来語) literally means 'words borrowed from foreign languages' (Hida, 1998). However, the words borrowed in relatively recent times from European languages exclude Kango even when they were actually borrowed from China (Iwabuchi, 1993; Shibata, 1993). The fourth category will be is Konshugo (混種語) literally means 'combination words'. Kindaichi et al. (1988: 424) define Konshugo (混種語) as words that combine two or more word categories. They give three basic types: 1 . combinations of Wago plus Kango, 2. Kango plus Gairaigo, and 3. Wago plus Gairaigo. For example, Wago plus Kango e.g. ishidan 石段 (stone stairs); Wago plus a Gairaigo e.g. bōrugami ボ ール紙 (cardboard), and Kango plus a Gairago e.g hanzubon 半ズボン (short pants). According to Kato (1990: 79), the use of vocabulary in Japanese oral language can be divided into Wago 46.9\%, Kango $40.0 \%$, Gairaigo 10.1\%, and Konshugo 3.0\%. In other words, the students learning JFL who want to master Japanese vocabulary well should memorize the correct pronunciation or reading vocabulary according to wago, kango, gairaigo, and konshugo so that it does not sound awkward in Japanese communication. These differences sometimes can be confusing for students when searching or looking for some words in Japanese to communicate. In the case of Japanese numbers, it always troublesome for JFL students to memorize or to recall certain vocabulary because pronunciation or reading of numbers in Japanese can change from nominal numbers to dates or times. See the example below:

\begin{tabular}{|c|c|c|c|}
\hline Nominal numbers & Dates & Months & Time \\
\hline $\begin{array}{c}\alpha ん(\text { Yon) } \\
\text { Four }\end{array}$ & $\begin{array}{c}\text { よっかy(Yokka) } \\
4^{\text {th }}\end{array}$ & $\begin{array}{c}\text { しがつ(Shi Gatsu) } \\
\text { April }\end{array}$ & $\begin{array}{l}\text { よじ(Yo Ji) } \\
\text { Four o'clock }\end{array}$ \\
\hline $\begin{array}{l}\text { Lち(Shichi) } \\
\text { Seven }\end{array}$ & $\begin{array}{c}\text { なのか(Nanoka) } \\
7^{\text {th }}\end{array}$ & $\begin{array}{c}\text { しちがつ(Shichi Gatsu) } \\
\text { July }\end{array}$ & $\begin{array}{l}\text { しちじ(Shichi Ji) } \\
\text { Seven o'clock }\end{array}$ \\
\hline $\begin{array}{c}\text { きゅう(Kуuu) } \\
\text { Nine }\end{array}$ & $\begin{array}{c}\text { ここのか(Kokonoka) } \\
9^{\text {th }}\end{array}$ & $\begin{array}{c}\text { くがつ(Ku Gatsu) } \\
\text { September }\end{array}$ & $\begin{array}{r}<し ゙(K u ~ J i) \\
\text { Nine o'clock }\end{array}$ \\
\hline
\end{tabular}

Table 1: Numbers in Japanese 
Therefore, Japanese language instructors should be creative in finding solutions to overcome student's problems in mastering Japanese vocabulary with the use of media, games, teaching methods, teaching aids, or alternative platforms in the teaching and learning process. Furuhata-Turner (2013: 73) proposed that by using materials in which students are already interested, language instructors can expect that students will enhance and improve their language competencies. Moreover, interactive activities such as active participation and involvement in the activities designed will create a more learner-centred learning environment to encourage students to practice their Japanese language speaking skills, besides stimulating their critical thinking skills. Vocabulary teaching requires the use of fun and engaging media to help students understand Japanese vocabulary easily. This is supported by Krashen's Affective Hypothesis (2003) states that songs can be the best source to reduce stress and anxiety in foreign language learning because interesting song melodies and song lyrics can reduce 'affective filters' to create a relaxed and effective learning environment (Butzlaff, 2000, Johnson \& Memmott, 2006; Shen, 2009). Even singing songs can increase students' interest, enjoyment, and confidence in learning a foreign language. When students listen to a song, they are actually exposed to the pronunciation of the native speaker by using the correct pronunciation; and when they sing a song, they actually use that language. Besides, the rhythm and melody of the songs are very helpful for students to use vocabulary naturally (Farrug, 2008).

Selection of media such as songs is a practical method for teaching Japanese vocabulary because the song contains various emotional elements such as happy, sad, excited, and other emotional feelings that can touch the feelings of someone who listens to it. Even songs can provide a medium of pronunciation that is unconsciously stored in the memory of the brain. Similarly, songs have rhyming patterns, so they make lessons more enjoyable and interesting to students learning foreign languages. Meanwhile, the learners have fun during song-based activities as they become more willing to learn. Accordingly, learners can learn how to pronounce those words in no time. Thornbury (2002) clarifies that the new vocabulary is easily acquired and recalled in a short time with the help of sound. Besides, the students are highly exposed to new vocabulary through songs since the words are repeated.

Although research on the use of songs in Japanese language teaching is not widely conducted locally or abroad, there are still some studies on the use of songs in learning foreign languages other than Japanese, such as English (Brett et al., 1996; Zimmerman, 1997 ) Spanish (Pressley, et al., 1980), French (Abrate, 1983), and Italian (Nuessel \& Cicogna, 1991). Among the studies conducted on the Japanese language is Hirano (2007) stated that using songs in Japanese language teaching classes can motivate students to study outside the Japanese language classroom. Also, Mori (2011) conducted a study on 30 Japanese language students at the University of Kansas who found that the use of songs is effective in the acquisition of transitive and intransitive verbs. However, not much information from the above study shows a positive or negative effect on the use of songs in learning Japanese.

Thus, the researcher took the initiative to make a study on the use of songs to improve the vocabulary of JFL students in Malaysia. Starting from there, this study was conducted with two purposes, the first to analyze the relationship of song use with students' Japanese language vocabulary. The second purpose is to see the effect of the use of songs on psychomotor skills and affective students' learning of Japanese vocabulary after using songs 
created by researchers in lectures. The findings of this study are expected to guide to help teachers or teaching staff get more effective teaching and learning methods to improve the vocabulary mastery of students learning Japanese as a foreign language in Malaysia.

\section{Research Questions}

This study is carried out to answer the following research questions:

i) What is the perceptions of the respondents on the use of Japanese songs on the acquisition of basic Japanese vocabulary,

ii) What is the perceptions of the respondents on the use of Japanese songs on cognitive, psycho-motor and affective skills of students in learning Japanese vocabulary.

\section{Literature Review}

Highlights of the literature review indicate that basic problems in Japanese language proficiency are related to the problem of lack of Japanese vocabulary. The problem of lack of vocabulary among JFL students restricts students' ability to use Japanese fluently in spoken and written form (Ali, 1989; Mustafa, 2009; Lazim, 2010; Hieda \& Shabudin, 2014). Therefore, mastering Japanese vocabulary effectively will be the most important step before students can master the Japanese language well.

According to the Krashen Input Hypothesis (1982), the acquisition of new vocabulary will occur when the meaning of the new vocabulary is explained first to the students. The meaning of vocabulary can be conveyed using extra-linguistic teaching aids such as illustrations, movements, pictures, and real objects. According to Medina (2002), the use of songs in foreign language classes is in line with the Krashen Input Hypothesis (1982). This is because Japanese songs make it easier for students to learn and remember what has been taught in learning Japanese because of the relaxed and fun Japanese language learning environment (Yamato, 2006; Hirano, 2007). Then students will be more confident and sensitive than usual and easily acquire new vocabulary more effectively. This is supported by Falioni's (1993) statement that "the use of songs in foreign language classes is a method of teaching to focus on students and produce more committed students."

According to much research conducted throughout centuries, there are many philosophers, scientists, researchers, and teachers who have recognized the importance of music to improve language proficiency. This also been supported by research on the use of songs in foreign language lessons significantly improves learners listening and pronunciation skills, and it plays a huge role in their overall development (Li \& Brand, 2009; Xioawei, 2010; Burhayani,2013; Borisai and Dennis, 2016). The literature review shows that the use of songs can improve skills in learning Japanese explicitly or implicitly. In addition to the song is an effective motivational tool that encourages students to focus on the process of teaching and learning Japanese. Although many studies have been conducted on foreign language vocabulary mastery, however, no previous studies have been conducted related to Japanese language vocabulary mastery among students in Malaysia. Therefore, there is a need to conduct this study. The purpose of this study is to identify the relationship between the use of songs created by researchers and the vocabulary mastery of JFL students in Malaysia.

\section{Methodology}

A total of 100 male and female students from various races aged between 19 to 24 years who 
participated in the level $1 \mathrm{JFL}$ language program in Malaysian university as elective subjects were selected by "stratified random sampling" involved in this study. The research instrument consists of a set of questions divided into two parts. The first part is an open-ended question about the demographics of the respondents. The second part is a question regarding students' perceptions of the use of selected Japanese songs in improving their vocabulary.

Observations were also conducted to obtain additional information not obtained from the questionnaire questions. The five songs that had been composed, sang, and recorded in $\mathrm{mp} 3$ format which is short, simple, and match the vocabulary found in the textbook "Minna no Nihongo". These Japanese songs have been uploaded in the learning e-portal to be accessible inside and outside the classroom. The respondents were asked to fill out a set of questionnaire questions in the 14th week of semester 2 of the 2019/20 session to obtain research data on students' perceptions of the effect of songs used in the JFL classroom.

Five Japanese songs written by the researcher and then been composed and sung by a professional composer cum singer were used as a research instrument in this study. The criteria to compose these songs were based on literature reviews that popular songs and Youtube songs are not suitable as learning material for this study. Moreover, these popular songs are written not according to the syllabus of the subject taught in the classroom (Nation $\&$ Webb, 2011). Nation (2007) suggested that for incidental vocabulary learning to take place, the materials used needed to be interesting to the learners. This condition would motivate learners and foster learning. The rhythm and melody of each song were written and composed in a catchy tune to attract students to absorb the vocabulary faster and effectively. Each song has a different melody, and the tune is from a slow to fast genre. The process of producing the songs took 6 months to be completed and then uploaded to the e-learning platform for the students to use it anytime and anywhere for learning the vocabulary taught in the JFL classroom. This is a complication of five songs accompanied by a songbook module to be used while listening to the songs. Below is the sample of the $C D$ of the five songs produced by the researcher to be used in this study.

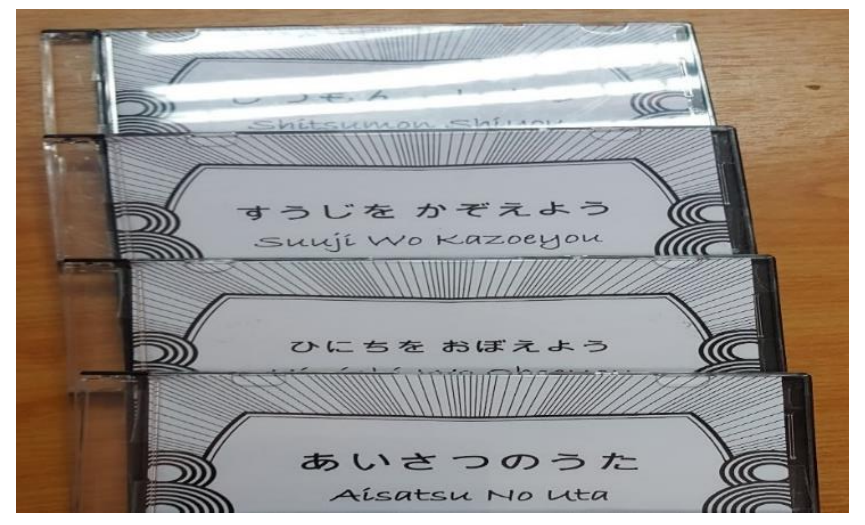

Figure 1: Complication of 5 Songs used in the research

\section{Findings}

The data collected were analysed using SPSS version 20 to obtain the results of the study on the perception of the respondents on the use of Japanese songs in improving their vocabulary proficiency. Besides, observations were used to obtain additional study data not obtained in the questionnaire. Study data collected from the respondents were grouped into several 
categories and then summarized. The results are as shown below.

\section{Feedback of Respondents on the Song Used}

Respondents were asked to evaluate themselves on the songs used in this study. The results of the responses collected from the self-assessment form are as recorded in Table 1.

FEEDBACK (\%)

\begin{tabular}{ccccc}
\hline Songs & & & & \\
& Like Extremely & Like & Dislike & Dislike \\
\hline & & & & extremely \\
動詞(Doushi) & 83.0 & 17.0 & 0 & 0 \\
数字(Suuji) & 85.0 & 15.0 & 0 & 0 \\
質問 & 87.0 & 13.0 & 0 & 0 \\
(Shitsumon) & & & & 0 \\
日日(Hinichi) & 90.0 & 10.0 & 0 & 0 \\
挨拶(Aisatsu) & 95.0 & 5.0 & 0 & \\
\hline
\end{tabular}

Table 2: Feedback of Respondents $\mathrm{N}=100$

From the answers, it is clear that all the respondents liked the five songs created by the researcher and none of the respondents did not like the songs used in this study. Nearly $80 \%$ of the respondent like extremely the song entitled (Doushi), 数字 (Suuji), 質問 (Shitsumon) and $20 \%$ of the respondent like it. While $90 \%$ of the respondents like extremely the songs 日 日 (Hinichi), 挨拶 (Aisatsu) and 10\% liked it. This conclusion shows that the respondents are fun with song integration in Japanese vocabulary teaching and learning. The findings of this study are in line with the findings of Abrate (1983), Bancroft (1999), Brady (1980), Gatti-Taylor (1980), Little (1983), Melpignano (1980), and Pyper (2005) that everyone likes the song used in the teaching and learning of foreign languages.

Perceptions of the respondents on the use of Japanese songs on the acquisition of basic Japanese vocabulary

The findings of the study show that almost $90 \%$ of the respondents agree that Japanese songs help them to recognize and remember vocabulary more effectively. This is because as the respondents repeatedly sang Japanese songs, their confidence level increased and their constraints to master new vocabulary decreased. This is in line with Li \& Brand's (2009) statement that "song rhythm with repetitive lyrics is a vehicle to increase students' vocabulary memory level in language learning and other language skills proficiency such as grammar structure and pronunciation among English students as a second language."

Further, the findings of the study show that almost all the respondents agree that the use of Japanese songs in learning Japanese is very interesting. The respondents stated that the use of Japanese songs can increase interest and help them to memorize more effectively through Japanese rhyme songs. In fact, some studies have stated that the use of Japanese songs is more interesting than conventional lectures. Besides, the Japanese language learning environment will be more interactive as the use of songs will involve interactions between Japanese language instructors and respondents. 
The data also show that the use of songs can help the respondents to pronounce new vocabulary better. The respondents during the observation had stated the rhythm and melody of the Japanese songs heard over and over as if recorded in their memory. This makes the respondents able to recall and recite the vocabulary learned in Japanese songs more effectively. The use of songs in language learning improves memorization. This is evidenced in several studies showing that song and rhythm can improve the memorization memory of foreign language students (Deutch, 1972; Palermo, 1978; Serafina et al, 1984; Borchgrevink, 1982).

Respondents were excited to make vocabulary exercises related to Japanese songs introduced in Japanese language teaching classes. They did their best to try to learn the lyrics of Japanese songs even though they were ashamed to sing loudly. Due to time constraints, elearning portals are used as a platform for respondents to upload and listen to Japanese songs repeatedly according to their convenience. Besides, the meaning of new vocabulary or lyrics has been distributed in the respondents to understand the Japanese songs. Continuous monitoring was done by collecting respondent marks in vocabulary training in the form of an excel file and was summed up on the 14th weekend of semester 2 of the 2019/2020 session. The overall marks of the respondents showed continuous vocabulary proficiency progress from the first exercise to the last vocabulary exercise carried through the study.

\section{Perceptions of the respondents on the use of Japanese songs on cognitive, psycho-motor and affective skills of students in learning Japanese vocabulary}

Findings show that almost all respondents feel focused on learning Japanese vocabulary in the classroom because they are directly involved in song singing activities. They feel fun and happy to be able to make movements related to the song they sang during the related vocabulary learning process. Besides, the respondents stated that they did not feel bored and lost focus as their senses moved actively throughout the singing activity. This is in contrast to conventional classes that make the respondents sit and copy the notes given by the lecturer.

The process of language flow in song singing is ensured by the use of various linguistic verbal intelligence such as visual-spatial intelligence, for example like reading lyrics; kin-aesthetic or psycho-motor intelligence, for example like clapping or dancing to the beat; and chanting as a whole group, they use interpersonal intelligence. This process facilitates foreign language acquisition because the fun in the song helps foreign language learners develop their instincts to recognize the linguistic features of the target language through singing (Christion, 1995; Wiggins, 2007). The affective aspect of the respondents also developed with the use of Japanese songs because the respondents had to show their emotions while singing the songs. This is because the song contains various emotional elements such as happy, sad, enthusiastic, and other emotional feelings that can touch the feelings of someone who listens to it.

The respondents stated that song is an effective motivational tool to reduce learning stress and anxiety. As shown by Butzlaff (2000), the nature of fun songs, rhythmic music, and song lyrics can help create a relaxed, effective, and low-stress learning environment, and therefore foster positive emotional states among students. Thus, music and songs can function directly by motivating students to learn Japanese, lowering "affective filters" and bringing maximum stimuli and effective language acquisition (Butzlaff, 2000; Johnson \& Memmott, 2006). This is in line with the findings of Yamato (2006) and Hirano (2007) that Japanese songs make it 
easier for students to learn and remember what has been taught in learning Japanese because of the relaxed and fun Japanese learning environment.

\section{Conclusions}

The use of Japanese songs in teaching new vocabulary to students can increase motivation and interest so that students feel fun and do not feel bored in the process of teaching and learning Japanese. The use of Japanese songs that attract rhythm helps students to memorize and remember Japanese vocabulary more effectively. Therefore, the use of songs in the teaching of Japanese vocabulary has a positive effect on improving the mastery of Japanese vocabulary of students in a Malaysian university. Even the cognitive, psycho-motor, and affective aspects develop in line with the acquisition of student vocabulary throughout the process of learning Japanese vocabulary occurs.

\section{Theoretical and Contextual Contribution}

This study is significant as it contributes to the stakeholders' understanding on the effectiveness between the composed songs and vocabulary acquisition. It will a new teaching approach for foreign language instructors in maximizing songs in teaching and learning new vocabulary. Moreover, using Japanese songs in teaching new vocabulary to students can increase motivation and interest so that students feel fun and do not feel bored in the process of teaching and learning Japanese. Therefore, the use of songs in the teaching of Japanese vocabulary has a positive effect on improving the mastery of new Japanese vocabulary of students in a Malaysian university.

\section{Corresponding Author}

Dr. Muhammad Alif Redzuan Abdullah

Universiti Putra Malaysia

\section{References}

Abrate, J. H. (1983). Pedagogical Applications of the French Popular Song in the Foreign Language Classroom. The Modern Language Journal, 67.

Ali, S. (1989). An Examination of Case Particle Errors in the Written Work of Malay Learners of Japanese. Unpublished M.A. Thesis, Universiti Malaya.

Arnaud, P., \& Savignon, S. (1997). Rare words, complex lexical units and the advanced learner.In: Coady, J., Huckin, T. (Eds.), Second language vocabulary acquisition: A rationale for pedagogy, 157 - 173. Cambridge University Press.

Barcroft, J. (2012). Input-based Incremental Vocabulary Instruction. TESOL International Association Press.

Bancroft, J. (1999). Suggestopedia and Language Acquisition: Variations on a Theme. New York: Gordon and Breach Publishers.

Brady, A. D. (1980). Opera as a Motivating Device. Foreign Language Annals, 6.

Brett, A., Rothlein, L. \& Hurley, M. (1996). Vocabulary Acquisition from Listening to Stories and Explanations of Target Words. The Elementary School Journal, 96 (4).

Borchgrevink, H. (1982). Prosody and Musical Rhythm are Controled by the Speech Hemisphere. In M. Clynes (Ed.), Music, Mind and Brain. NewYork: Plenum Press.

Borisai, T., \& Dennis, N. K. (2016). A Study of Using Pop Songs to Promote New Vocabulary Learning for Secondary School Students". International Journal of ResearchGranthaalayah, 4(1), 86-92. 
Brown, C. (1993). Factors affecting the acquisition of vocabulary: Frequency and saliency of words." In T. Huckin \& M. Haynes \& J. Coady (Eds.), Second language reading and vocabulary learning. Norwood, New Jersey: Prentice Hall.

Burhayani, E. (2013). The Effectiveness of Teaching Vocabulary through Songs to the Second Years Students of Ikatan Keluarga Kesejahteraan Tentara (IKKT) Elementary School West Jakarta. Proceedings of $2^{\text {nd }}$ International Seminar on Quality and Affordable Education, 2 69-73. Universiti Teknologi Malaysia.

Butzlaff, R. (2000). Can Music be Use to Teach Reading? Journal of Aesthetic Education, 34.

Christison, M. A. (1995). English through Poetry. San Francisco: Alta Books.

Deutsch, D. (1972). Music and Memory." Psychology Today, 6.

Farrug, D. (2018). How Music Helps Language Learning. Retrieved from language study: http://languagestudy.suite101.com/article.cfm/why_use_music_to_learn_language, 2018.

Falioni, J. W. (1993). Music as Means to Enhance Cultural Awareness and Literacy in the Foreign Language Classroom. Mid-Atlantic Journal of Foreign Language Pedagogy, 7.

Furuhata-Turner, H. (2013). Use of comic manga as a learning tool to teach translation of Japanese. The Journal of Language Teaching and Learning, 3(2), 72-83.

Gatti-Taylor, M. (1980). Songs as a Linguistic and Cultural Resource in the Intermediate Italian Class. Foreign Language Annals.

Hida, Y. (1998). Gairaigo no toriirekata no henka. Nihongogaku 17 (7), 29-38.

Hieda, N., \& Shabudin, M. (2014). Sikap Mahasiswa UKM Terhadap Bahasa Jepun: Satu Kajian Kes. GEMA ONLINE Journal of Language Studies 14 (1):135- 150

Hirano, E. (2008). The effects of Utilizing Japanese Songs for Acquiring Japanese Pitch as a Foreign Language. Paper presented at the Annual Meeting of the Central Association of Teachers of Japanese, University of Wisconsin-Madison. United States of America.

Iwabuchi, E. (1993). Gairaigo. In Kawadeshobō (Ed.), Kotobadokuhon gairaigo. Kawadeshobō-shinsha, Tokyo.

Johnson, C. M. \& Memmott, J. E. (2006). Examination of Relationships between Music Programs of Differing Quality and Standardized Test Results. Journal of Research in Music Education, 54(4).

Kindaichi, H., Hayashi, O., \& Shibata, T. (1998). An encyclopaedia of the Japanese language. Tokyo: Taishūkan.

Krashen, S. (1982). Principles and Practice in Second Language Acquisition. Oxford: Pergamon Press.

Krashen, S. (2003). Explorations in Language Acquisition and Use. Portsmouth: Heinemann.

Lazim, A. S. (2010). Two Decade on Looking East Policy: Evaluation Aspect on Education (1982-2002). Tanjung Malim: UPSI Publisher.

Li, X., \& Brand, M. (2009). Effectiveness of Music on Vocabulary Acquisition, Language Usage, and Meaning for Mainland Chinese ESL learners. Contributions to Music Education, 36(1).

Little, J. (1983). Pop and Rock Music in the ESL Classroom." TESL Talk, 14 (4).

Medina, S. (2002). Acquiring Vocabulary through Story-Songs. MEXTESOL Journal, 23(1), 287.

Meara, P. (1980). Vocabulary acquisition: A neglected aspect of language learning. Language teaching and linguistics abstracts, 13, 221- 246.

Melpignano, R. J. (1980). A different use for French songs in the classroom. Foreign Language Annals, 6. 
Mustafa, Z. (2009). Error Analysis in Malay Students' Japanese Language Composition in Universiti Malaya. Jurnal Bahasa dan Budaya Jepun.

Nation, I. S. P. (2007). The four strands. International Journal of Innovation in Language Learning and Teaching, 1(1), 1-12.

Nation, I. S. P., \& Webb, S. (2011). Researching and analyzing vocabulary. Boston: Heile.

Nuessel, F., \& Cicogna, C. (1991). The Integration of Songs and Music into the Italian Curriculum. Italica, 68(4).

Palermo, D. (1978). The Psychology of Language. Illinois: Scott, Foresman and Company,.

Pressley, M., Levin, J. R., Hall, J. W., Miller, G. E., \& Berry, J. K. (1980). The Keyword Method and Foreign Word Acquisition. Journal of Experimental Psychology, 6.

Pyper, M. J. (2005). Music and Motivation in the Second Language College Classroom. Dissertation Abstracts International." The Humanities and Social Sciences, 67 (2).

Serafine, M., Crowder, R., and Repp, B. (1984). Integration of Melody and Test in Memory for Songs. Cognition, 16 (3).

Shen, H. H. (2009). Size and Strength: Written Vocabulary Acquisition among Advanced Learners. Chinese Teaching in the World, 23 (1).

Shibatani, M. (1990). The languages of Japan. New York: Cambridge University Press.

Tanaka, A. (1984). Goshuron no kadai." Nihongogaku, 3(9), 7-17.

Thornbury, S. (2002). How to teach vocabulary. England: Pearson Education Limited.

Umesao, Kindaichi, H., Sakakura, A. \& Hinohara, S. (1989). Nihongodaijiten. Tokyo: Kōdansha,

Wiggins, D. G. (2007). Pre-K Music and the Emergent Reader: Promoting Literacy in a Music Enhanced Environment. Early Childhood Education Journal, 35(1).

Wilkins, D. (1972). Linguistics in language teaching. London: Arnold,.

Yamato, E. (2006). Nihon Drama Shichoo to Nihongo Gakushu (Watching Japanese Drama and Learning Japanese Language). Nihongakukan, 10.

Xiaowei, F. (2010). Strategies of Learning English Vocabulary from Pop Songs. English IV, Spring.

Zimmerman, C. B. (1997). Do Reading and Interactive Vocabulary Instruction Make a Difference? An Empirical Study. TESOL Quarterly, 31(1). 